\title{
Quad Screen
}

National Cancer Institute

\section{Source}

National Cancer Institute. Quad Screen. NCI Thesaurus. Code C92865.

A screening measurement in which the maternal blood levels of alpha-fetoprotein, unconjug ated estriol, human chorionic gonadotrophin and Inhibin A are calculated. These are then evaluated in relation to the mother's age, weight and fetal gestational age. 